\title{
Biomass spectra and stable isotope indicators of trophic level in zooplankton of the northwest Atlantic
}

\author{
Brian Fry ${ }^{1, *}$, Renato B. Quiñones ${ }^{2}$ \\ ${ }^{1}$ Ecosystems Center, Marine Biological Laboratory, Woods Hole, Massachusetts 02543, USA \\ ${ }^{2}$ Instituto de Fomento Pesquero, Zonal Talcahuano, Colon 3656, Talcahuano, Chile
}

\begin{abstract}
We collected size-fractionated zooplankton samples from Georges Bank, the Gulf of Maine and 2 stations in the Sargasso Sea to test whether regular patterns of biomass decrease in the mesozooplankton community are accompanied by an increase in trophic level. Using stable nitrogen and carbon isotopic compositions as trophic level indices, we generally found small changes in trophic level $(<0.5$ to 0.75 trophic level units) across 7 zooplankton size fractions ranging from 64 to $8000 \mu \mathrm{m}$. The results indicate a large degree of trophic level overlap among the various zooplankton size classes. Decreases in biomass were accompanied by increases in average trophic level among larger zooplankton for all regions studied, suggesting that, in addition to metabolic factors, trophic dynamics can be important in controlling observed patterns of biomass decrease in planktonic communities.
\end{abstract}

KEY WORDS: Biomass spectra 'Stable isotopes $\cdot \delta^{13} \mathrm{C} \cdot \delta^{15} \mathrm{~N}$. Zooplankton

Biomass size-spectra have been constructed for many lake and ocean ecosystems, and usually show a regular decline in average biomass as the average size of organisms increases. Regular changes in biomass have led to the development of several theoretical models attempting to explain and quantify these biomass changes (e.g. Kerr 1974, Sheldon et al. 1977, Borgmann 1987, Dickie et al. 1987, Keifer \& Berwald 1992). Most models include in their formulation the trophic level concept, with biomass decreases reflecting the dissipation of energy across trophic levels. However, some models are independent of the trophic level formalism (e.g. Platt \& Denman 1977, 1978) and assume a continuous flux of energy from organisms of small size to those of larger size. One might generally expect an increase in

\footnotetext{
- Present address: Biology Department, Florida International University, University Park, Miami, Florida 33199, USA
}

trophic level with increasing size, but because it has been difficult to assign trophic levels to planktonic organisms, the importance of trophic level changes in community size-distributions has been little tested.

Here we present results from cruises conducted in the northwest Atlantic during August and September 1988 designed to test for trophic level changes with increasing body size in the zooplankton community. We made stable isotope measurements of zooplankton trophic level at 4 locations, analyzing $\delta^{15} \mathrm{~N}$ and $\delta^{13} \mathrm{C}$ of size-fractionated mixed zooplankton samples from the central Gulf of Maine, Georges Bank, and the Sargasso Sea. The isotope indicators have been calibrated in previous aquatic field studies such that 1 trophic level increase corresponds to about $1 \%$ for $\delta^{13} \mathrm{C}$ and $3.4 \%$ $\delta^{15} \mathrm{~N}$ (Fry \& Sherr 1984, Minagawa \& Wada 1984). Our intent was to use these isotope indicators to test the possible importance of trophic level in controlling regular patterns of biomass decline with increasing zooplankton size.

Sampling and methods. Zooplankton were collected in August 1988 in well-mixed frontal waters of northeastern Georges Bank (41 $53.72^{\prime}$ N, 66 $49.12^{\prime}$ W) and in nearby stratified waters of south-central Gulf of Maine $\left(42^{\circ} 19.87^{\prime} \mathrm{N}, 66^{\circ} 48.59^{\prime} \mathrm{W}\right)$. Samples from the Sargasso Sea were collected the following month from 2 stations $\left(35^{\circ} 56.04^{\prime} \mathrm{N}, 64^{\circ} 20.51^{\prime} \mathrm{W}\right.$ and $36^{\circ} 02.17^{\prime} \mathrm{N}$, $65^{\circ} 09.27^{\prime} \mathrm{W}$ ).

Zooplankton were collected in vertical tows (64 or $75 \mu \mathrm{m}$ mesh nets) and oblique tows $(250 \mu \mathrm{m}$ mesh nets), and fractionated with metal sieves aboard ship into the following size classes (in $\mu \mathrm{m}$ ): 64 or $75-125$, $125-250,250-500,500-1000,1000-2000,2000-4000$, and 4000-8000. To convert from lengths to carbon units, we used midpoints of the length classes and published conversion factors (Rodriguez \& Mullin 1986). Using these conversions, the length size classes corre- 
spond to the following carbon size classes (average $\mu \mathrm{g}$ C per individual: $0.07,0.3,1.4,7.6,32,149$, and 699).

The biomass size-spectra were normalized and plotted on a log-log scale as described by Platt \& Denman (1977, 1978). This normalization is required since the width of the size classes varies through the size spectra. In brief, the procedure consists of taking the variable of interest, $m(s)$, in the size class characterized by the weight or volume (s) and dividing it by the width of the size class, $\Delta s$. Thus, the normalized version of the variable $m$ is equal to:

$$
M(s)=m(s) / \Delta s .
$$

Aliquots of the size-fractionated zooplankton samples were dried at $60^{\circ} \mathrm{C}$. Zooplankton were not held to allow gut clearance, so dried animals included a minor amount of prey organic material. Carbon content was determined from CHN analyses (Perkin Elmer 240-B CHN Elemental Analyzer), and isotopic measurements made with an automated elemental analyzer coupled to an isotope ratio mass spectrometer (Fry et al. 1992). Carbonates were removed from zooplankton samples with dilute hydrochloric acid prior to $\delta^{13} \mathrm{C}$ analyses; samples for $\delta^{15} \mathrm{~N}$ analyses were not treated with acid. Isotopic values are reported relative to $\operatorname{PDB}\left(\delta^{13} \mathrm{C}\right)$ and air nitrogen $\left(\delta^{15} \mathrm{~N}\right)$. Analyses of replicates usually showed agreement at the $0.1 \%$ level or better.

Results. Zooplankton size spectra showed the expected regular declines in biomass with increasing size in all areas, although these patterns were more regular in the Sargasso Sea samples than in the samples from Georges Bank and the Gulf of Maine (Fig. 1, top panels). The overall amounts of zooplankton were lower in the Sargasso Sea samples than in the samples from the shelf stations (Fig. 1, compare normalized biomass estimates in similar size classes across the different systems).

The isotopic results showed regional differences, with each region having a different combination of $\delta^{15} \mathrm{~N}$ and $\delta^{13} \mathrm{C}$ values. For example, Sargasso Sea samples had low $\delta^{15} \mathrm{~N}$ but Georges Bank and Gulf of Maine samples had higher values (Fig. 1, middle panels), while for $\delta^{13} \mathrm{C}$, Sargasso Sea samples had high values, Gulf of Maine samples low values, and intermediate values occurred in samples from Georges Bank (Fig. 1, bottom). These regional differences were evident across all size classes of zooplankton, suggesting that such differences arise at lower trophic levels, probably among phytoplankton consumed by zooplankton. We could not directly test this because of the difficulties of isolating sufficient quantities of phytoplankton for isotopic analyses, but analysis of a few samples of mixed particulate organic matter collected on filters showed regional $\delta^{15} \mathrm{~N}$ differences similar to those encountered in the zooplankton samples. Thus, we measured 0.6

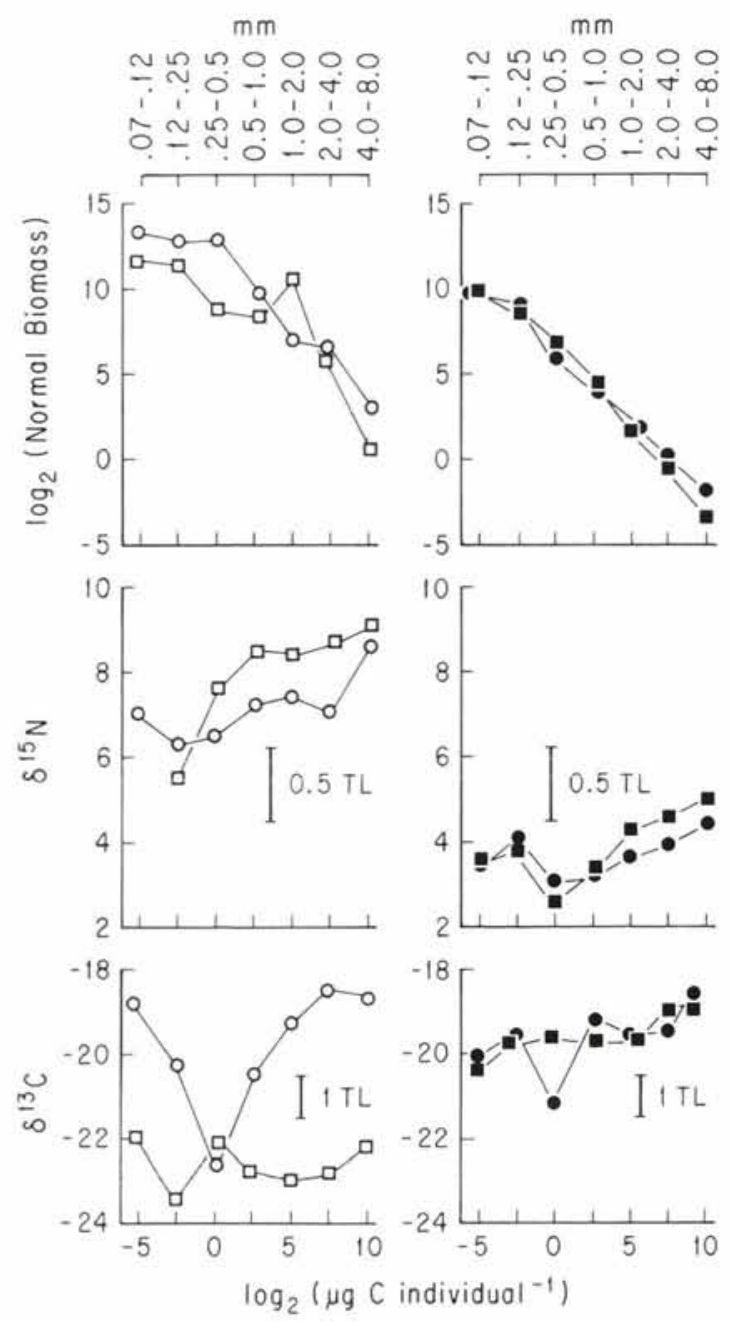

Fig. 1. Size and isotopic changes among zooplankton from Georges Bank (O) and the Gulf of Maine ( $\square$ ) and 2 stations in the Sargasso Sea $(\boldsymbol{0})$. Top panels: size spectra of zooplankton (from Quiñones 1992). Middle panels: $\delta^{15} \mathrm{~N}$ of size fractions, with a one-half trophic level (TL) of $1.7 \%$ indicated for scale. Bottom panels: $\delta^{13} \mathrm{C}$ of size fraction, with 1 trophic level $(1 \%)$ indicated for scale

and $1.1 \% \delta^{15} \mathrm{~N}$ values for 2 surface and chlorophyll maximum $(80 \mathrm{~m})$ samples collected in the Sargasso Sea, values considerably lower than 6 measured values of 4.8 to $6.0 \%$ for the Gulf of Maine and Georges Bank. We did not find a consistent difference in $\delta^{13} \mathrm{C}$ values of particulates between regions; we are currently using flow cytometric techniques to isolate phytoplankton directly for isotopic investigation of causes of the regional $\delta^{13} \mathrm{C}$ differences suggested by the current zooplankton results.

Within each region, we used literature estimates of isotopic change with trophic level to determine the range in trophic level among the zooplankton size 


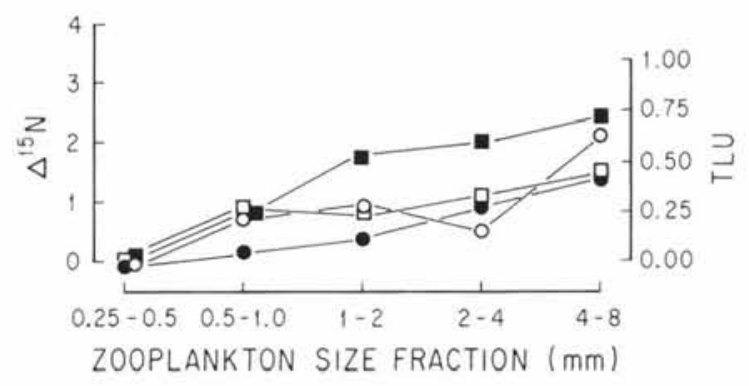

Fig. 2. Increases in ${ }^{15} \mathrm{~N}$ among larger zooplankton, calculated relative to $\delta^{15} \mathrm{~N}$ values of 250 to $500 \mu \mathrm{m}$ zooplankton. Scale at right (TLU: trophic level unit) assumes $3.4 \% \delta^{15} \mathrm{~N}$ increase per trophic level. Symbols as in Fig. 1

classes. We have taken a 1 trophic level unit change as $1 \% \circ \delta^{13} \mathrm{C}$ and $3.4 \% \delta^{15} \mathrm{~N}$ (Fry \& Sherr 1984, Minagawa \& Wada 1984), and according to these criteria, find changes generally smaller than 1 trophic level unit across the zooplankton classes in all systems studied.

The most regular increase in isotopic compositions occurred among the 5 larger size classes collected in the Sargasso Sea where the $\delta^{15} \mathrm{~N}$ overall changes were 1.3 and $2.4 \%$, corresponding to 0.37 and 0.69 trophic level units (Fig. 2). The 5 larger zooplankton classes on Georges Bank and in the Gulf of Maine showed less regular $\delta^{15} \mathrm{~N}$ increases, but increased overall $1.5 \%(0.43$ trophic level units) and 2.1\%o (0.60 trophic level units) respectively with increasing size. For these 5 larger size classes, changes in biomass were significantly correlated with $\delta^{15} \mathrm{~N}$ in all regions, and most consistently in the Sargasso Sea samples (Fig. 3). Significant $r^{2}$ values for linear regressions applying to data of Fig. 3 were 0.95

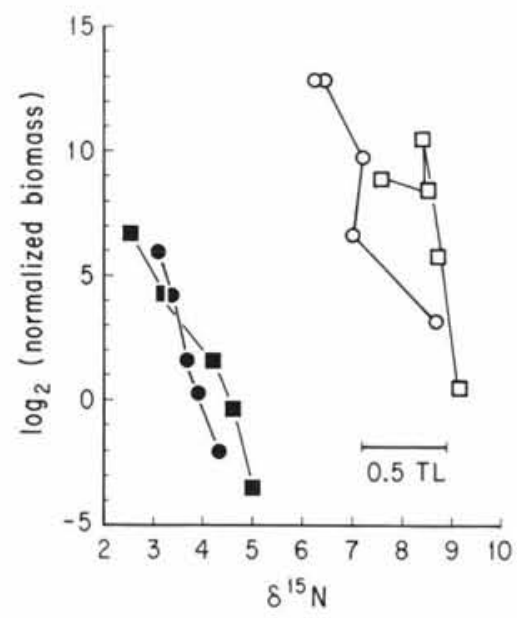

Fig. 3. Biomass decreases with increasing trophic level $\left(\delta^{15} \mathrm{~N}\right)$ among the 5 largest zooplankton size classes $(250 \mu \mathrm{m}$ upwards) in each study region. For reference, scale bar shows a $1.7 \% \delta^{15} \mathrm{~N}$ increase equivalent to a one-half trophic level (TL). Other symbols as in Fig. 1 and 0.98 for the 2 Sargasso Sea stations, 0.79 for Georges Bank, and 0.52 for the Gulf of Maine, while slopes were $-5.6,-4.1,-5.2$ and -4.2 respectively.

Carbon isotopic changes were generally much smaller than the nitrogen isotope changes (Fig. 1), and consistent with a somewhat irregular, but small trophic level change $(<1 \%$ or $<1$ trophic level) across the zooplankton size classes. The largest carbon isotopic changes occurred in the mixed Georges Bank frontal waters, where a nearly pure sample of Calanus finmarchicus in the $250-500 \mu \mathrm{m}$ size class had low $\delta^{13} \mathrm{C}$ values similar to those observed generally in the Gulf of Maine samples. Advection of Gulf of Maine C. finmarchicus populations onto Georges Bank may be responsible for these low $\delta^{13} \mathrm{C}$ values, rather than changes in trophic level.

Discussion. The isotopic results must be interpreted with care, especially since the actual amount of isotopic increase per trophic level is not known precisely, in spite of several field estimates. For example, there are some problems with using $\delta^{13} \mathrm{C}$ to indicate trophic level: the increase in $\delta^{13} \mathrm{C}$ with trophic level is small $(1 \%)$ relative to overall sampling errors, and it has been proposed that $\delta^{13} \mathrm{C}$ changes in food webs may more strongly reflect importance of ${ }^{13} \mathrm{C}$-rich diatom foodstuffs rather than simple trophic level (Fry \& Wainright 1991). There is currently more confidence in the use of $\delta^{15} \mathrm{~N}$ as a trophic level indicator, because these isotopic changes per trophic level are larger (average of $3.4 \%$ ) and have been repeatedly documented in aquatic systems (Minagawa \& Wada 1984, Fry 1988, Montoya et al. 1990, Kling et al. 1992). However, methodological difficulties have prevented us thus far from measuring $\delta^{15} \mathrm{~N}$ values of phytoplankton and microbial loop organisms separately from bulk particulate organic nitrogen, and we have little concrete information about isotopic changes in these smaller organisms that are important parts of planktonic food webs. Moreover, there are indications that the $3.4 \%$ per trophic level may not apply in this portion of the planktonic food web. Where bacterial processing of detrital foods is important, $\delta^{15} \mathrm{~N}$ changes across trophic levels seem considerably smaller than 3.4\% (Dunton et al. 1989, Meili et al. 1993).

There was some indication of a reduced nitrogen isotope trophic step $(<3.4 \%)$ for the smaller zooplankton of this study. For example, in the Sargasso Sea, small zooplankton in the $74-250 \mu \mathrm{m}$ ranges had $\delta^{15} \mathrm{~N}$ values only 2 to $3 \%$ higher than particulate organic ${ }^{15} \mathrm{~N}$ values, while for the Gulf of Maine and Georges Bank, this difference was smaller, only 1 to $2 \%$. These results suggest that the rule of $3.4 \%$ per trophic level is not inviolate. It may be that higher conservation of $\mathrm{N}$ occurs in trophic transfers of the microbial loop, leading to less overall isotopic nitrogen isotope fractionation. 
For larger zooplankton, however, we observed a more regular increase in $\delta^{15} \mathrm{~N}$ that suggested an overall trophic increase of about 0.5 trophic level units across the $250-8000 \mu \mathrm{m}$ size range (Fig. 2). This modest increase in trophic level agrees well with previous predictions. The nature of the predator-prey size feeding relationships in the sea was reviewed by Sheldon et al. (1977) who, after converting body sizes to the common axis of equivalent spherical diameters, found that copepods take prey an average of 20 to 30 times smaller than themselves, although Sheldon et al. (1977) also noted that some zooplankton fed on prey up to $100 \times$ smaller than themselves. Our size range categories for 250-8000 $\mu \mathrm{m}$, when converted to equivalent spherical diameters, are $0.41,0.82,1.65,3.3$ and $6.6 \mathrm{~mm}$, so that a factor of 16 exists across this size range, about half a trophic level using the criteria of Sheldon et al. (1977).

Our isotope-based trophic level estimates thus support the idea that changes in biomass distributions in aquatic systems correlate with trophic level changes (Fig. 3), with correlations being strongest in Sargasso Sea samples where biomass changes were most regular (Fig. 1). These findings support the arguments made previously (Dickie et al. 1987, Boudreau et al. 1991, Thiebaux \& Dickie 1993) that trophic organization as well as metabolism is an important structuring force behind the regular biomass spectra observed in aquatic systems. Further research is needed to clearly separate the roles of metabolism and trophic level in causing the observed changes in biomass spectra.

Finally, in agreement with previous oceanographic studies showing only modest $\delta^{15} \mathrm{~N}$ differences among various zooplankton taxa (Mullin et al. 1984, Montoya et al. 1992), we observed fairly small 1.4 to $2.4 \%$ o $\delta^{15} \mathrm{~N}$ changes across the zooplankton size classes. Overall, these results indicate only a modest increase in average trophic level with size in the mesozooplankton community. This small trophic level change is consistent with the idea that zooplankton mostly feed opportunistically in unstructured food webs (Isaacs 1972), or mostly feed on similar diets consisting of phytoplankton and microzooplankton smaller than $64 \mu \mathrm{m}$.

Acknowledgements. This work was supported by private funds from the Mellen Foundation and Grant DE-FG0292ER61438 from the U.S. Department of Energy.

\section{LITERATURE CITED}

Borgmann, U. (1987). Models on the shape of, and biomass flow up, the biomass size-spectrum. Can. J. Fish. Aquat. Sci. $40(11)$ : 2010-2018

This note was presented by R. S. Scheltema (Senior Editorial Advisor), Woods Hole, Massachusetts, USA
Boudreau, P. R., Dickie, L. M., Kerr, S. R. (1991). Body-size spectra of production and biomass as system-level indicators of ecological dynamics. J. theor. Biol. 152: 329-339

Dickie, M., Kerr, S. R., Boudreau, P. (1987). Size-dependent processes underlying regularities in ecosystem structure. Ecol. Monogr. 57: 233-250

Fry, B. (1988). Food web structure on Georges Bank from stable C, N, and S isotopic compositions. Limnol. Oceanogr. 33: $1027-1030$

Fry, B., Brand, W., Mersch, F. J., Tholke, K., Garritt, R. (1992). Automated analysis system for coupled $\delta^{13} \mathrm{C}$ and $\delta^{15} \mathrm{~N}$ measurements. Analyt. Chem. 64(3): 288-291

Fry, B., Sherr, E. (1984). $\delta^{13} \mathrm{C}$ measurements as indicators of carbon flow in marine and freshwater ecosystems. Contr. mar. Sci. 27: 13-47

Fry, B., Wainright, S. C. (1991). Diatom sources of ${ }^{13} \mathrm{C}$-rich carbon in marine food webs. Mar. Ecol. Prog. Ser. 76: $149-157$

Dunton, K. H., Saupe, S. M., Golikov, A. N., Schell, D. M., Schonberg, S. V. (1989). Trophic relationships and isotopic gradients among arctic and subarctic marine fauna. Mar. Ecol. Prog. Ser. 56: 89-97

Isaacs, J. D. (1972). Unstructured marine food webs and 'pollutant analogues'. Fish. Bull. 70: 1053-1059

Keifer, D. A., Berwald, J. (1992). A random encounter model for the microbial planktonic community. Limnol. Oceanogr. 37: 457-467

Kerr, S. R. (1974). Theory of size distribution in ecological communities. J. Fish. Res. Bd Can. 31: 1859-1862

Kling, G. W., Fry, B., O'Brien, W. J. (1992). Stable isotopes and planktonic structure in arctic lakes. Ecology 73: 561-566

Meili, M., Fry, B., Kling, G. W. (1993). Fractionation of stable isotopes $\left({ }^{13} \mathrm{C},{ }^{15} \mathrm{~N}\right)$ in the food web of a humic lake. Verh. int. Verein. Limnol. 25: 501-505

Minagawa, M., Wada, E. (1984). Stepwise enrichment of ${ }^{15} \mathrm{~N}$ along food chains: further evidence and the relation between $\delta^{15} \mathrm{~N}$ and animal age. Geochim. cosmochim. Acta 48: $1135-1140$

Montoya, J. P., Wiebe, P. H., McCarthy, J. J. (1992). Natural abundance of ${ }^{15} \mathrm{~N}$ in particulate nitrogen and zooplankton in the Gulf Stream region and warm-core ring $86 \mathrm{~A}$. Deep Sea Res. 39 (Suppl. 1): S363-S392

Mullin, M. M., Rau, G. H., Eppley, R. W. (1984). Stable nitrogen isotopes in zooplankton: some geographic and temporal variations in the North Pacific. Limnol. Oceanogr. 29: $1267-1273$

Platt, T., Denman, K. (1977). Organization in the pelagic ecosystem. Helgoländer wiss. Meeresunters. 30: 575-581

Platt, T, Denman, K. (1978). The structure of pelagic ecosystems. Rapp. P.-v, Réun. Cons. int. Explor. Mer 173: 60-65

Quiñones, R. A. (1992). Size distribution of planktonic biomass and metabolic activity in the pelagic system. Ph.D. thesis, Dalhousie University, Halifax

Rodriguez, J., Mullin, M. (1986). Relationship between biomass and body weight of plankton in a steady state oceanic ecosystem. Limnol. Oceanogr. 31:361-370

Sheldon, R. W., Sutcliffe, W. H. Jr, Paranajape, M. A. (1977). Structures of pelagic food chain and relationship between plankton and fish production. J. Fish. Res. Bd Can. 34: 2344-2355

Thiebaux, M. L., Dickie, L. M. (1993). Structure of the bodysize spectrum of the biomass in aquatic ecosystems: a consequence of allometry in predator-prey interactions. Can. J. Fish. Aquat. Sci. 50: 1308-1317

Manuscript first received: November 23, 1993

Revised version accepted: June 8, 1994 